\title{
GEOLOGICAL NOTES
}

\section{An Exhumed Late Paleozoic Canyon in the Rocky Mountains}

\author{
Gerilyn S. Soreghan, ${ }^{1}$ Dustin E. Sweet, Kristen R. Marra, Cortland F. Eble, ${ }^{2}$ \\ Michael J. Soreghan, R. Douglas Elmore, Sara A. Kaplan, \\ and Michael D. Blum ${ }^{3}$
}

School of Geology and Geophysics, University of Oklahoma, 100 East Boyd Street, Norman, Oklahoma 73019-1009, U.S.A.

(e-mail: 1soreg@ou.edu)

\begin{abstract}
A B S T R A C T
Landscapes are thought to be youthful, particularly those of active orogenic belts. Unaweep Canyon in the Colorado Rocky Mountains, a large gorge drained by two opposite-flowing creeks, is an exception. Its origin has long been enigmatic, but new data indicate that it is an exhumed late Paleozoic landform. Its survival within a region of profound late Paleozoic orogenesis demands a reassessment of tectonic models for the Ancestral Rocky Mountains, and its form and genesis have significant implications for understanding late Paleozoic equatorial climate. This discovery highlights the utility of paleogeomorphology as a tectonic and climatic indicator.
\end{abstract}

Online enhancement: appendix.

\section{Introduction}

Most geologists view landforms to be "young" a priori, a concept that dates to the works of James Hutton (1788), who considered landscapes youthful owing to constant renewal of Earth's surface (Twidale 1998). The possibility of the great antiquity of landscapes remains underappreciated despite discovery of growing numbers of pre-Cenozoic landforms (Twidale 1976, 1994), particularly in cratonal regions of the Gondwanan continents but also in, for example, the Precambrian Shield regions of North America (Ambrose 1964). In this note, we present evidence for the late Paleozoic age and late Cenozoic exhumation of a major canyon in a region of the western United States that experienced active orogenesis in both the late Paleozoic and Cenozoic. The great antiquity of this canyon reconciles many enigmatic aspects of its modern presence but forces a reexamination of its Paleozoic genesis and sur-

\footnotetext{
Manuscript received June 23, 2006; accepted January 8, 2007.

${ }^{1}$ Author for correspondence.

${ }^{2}$ Kentucky Geological Survey, University of Kentucky, Lexington, Kentucky 40506-0107, U.S.A.

${ }^{3}$ Department of Geology and Geophysics, Louisiana State University, Baton Rouge, Louisiana 70803, U.S.A.
}

vival, with broader implications for the tectonic and climatic histories of this and other regions. This example highlights the potential persistence of ancient landscapes within even active orogenic belts and the utility of paleogeomorphology as a tool for tectonic and climatic reconstructions.

\section{Geologic Setting: The Mystery of Unaweep Canyon}

The modern Uncompahgre Plateau (fig. 1) is a large Precambrian-cored uplift situated at the northeast margin of the broader Colorado Plateau, a region of Cenozoic epeirogenic uplift. The late Paleozoic precursor to the modern Uncompahgre Plateau was the Uncompahgre uplift, one of several basementcored highlands of the Ancestral Rocky Mountains (ARM), which was ultimately buried by Mesozoic strata. The timing and mechanism of Cenozoic uplift on the Colorado Plateau, as well as its drainage evolution, remain controversial (e.g., Morgan and Swanberg 1985; Spencer 1996; McQuarrie and Chase 2000; Pederson et al. 2002). The Unaweep Canyon of the Uncompahgre Plateau has been rec- 


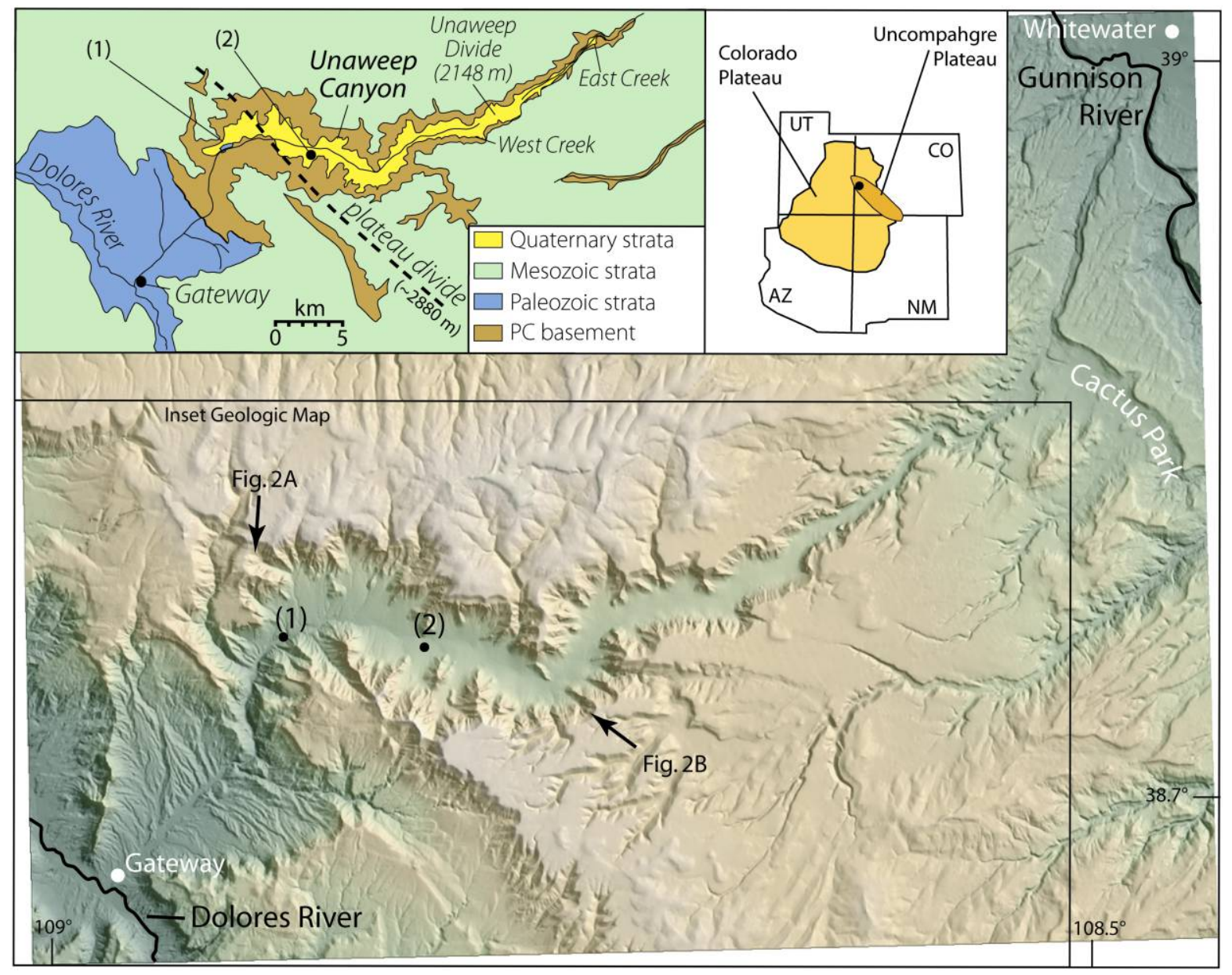

Figure 1. Digital elevation model of Unaweep Canyon, with key features noted in text. 1 denotes the outcrop discussed in the text and shown in figure 3,2 denotes the location of the well discussed in the text and shown in figure 4. Note locations of views shown in figure 2. Inset shows the location of Unaweep Canyon on the Colorado and Uncompahgre Plateaus and a simplified geologic map of Unaweep Canyon.

ognized as an enigmatic landform at least since the Hayden Survey (Peale 1877; Gannett 1882), a fact highlighted by its Ute Indian name, which means "dividing of waters" or "canyon with two mouths." The canyon is about $1 \mathrm{~km}$ deep and $6 \mathrm{~km}$ wide with a smaller gorge ( $400 \mathrm{~m}$ deep, $800 \mathrm{~m}$ wide) inset. It cuts through Mesozoic strata and crystalline basement and is oriented perpendicular to the northwest-southeast-trending Uncompahgre Plateau. It is drained by two underfit streams (East Creek and West Creek) flowing from an indeterminate divide standing at $2148 \mathrm{~m}$ elevation to join the nearest large rivers to the northeast (Gunnison River) and the southwest (Dolores River; fig. 1).

The anomalous orientation, size, and longitudinal profile of Unaweep Canyon have given rise to varied hypotheses for its origin. All authors rec- ognize that the two creeks draining the canyon could not have carved it. Most have suggested canyon cutting in the Pliocene or Pleistocene by either the ancestral Gunnison River (e.g., Peale 1877; Cater 1966; Sinnock 1981), which flowed through the San Juan volcanic province, or the ancestral Colorado River (possibly including the Gunnison; e.g., Gannett 1882; Hunt 1956; Lohman 1961, 1981; Steven 2002). Oddly, however, gravels marking the presence of an ancestral river are absent from the main canyon. Some have appealed to recent uplift to explain the existence of Unaweep Divide (e.g., Lohman 1965; Cater 1966; Hunt 1969; Perry and Annis 1990); however, structural evidence for such significant uplift (400-600 m; Cater 1966) is absent (Aslan et al. 2005). Geomorphic features of the inner gorge such as apparent cirques, truncated spurs, 
and hanging valleys have led some (Lohman 1981; Cole and Young 1983) to suggest a Pleistocene glacial origin, but Pleistocene ice in the region did not extend lower than $2750 \mathrm{~m}$ (Yeend 1969), at least $600 \mathrm{~m}$ above the highest point in the canyon (Unaweep Divide). Also, no moraines have been identified in or near the canyon.

Recent mapping, provenance studies, and paleocurrent analysis of gravels outside the western mouth of Unaweep Canyon confirm that the ancestral Gunnison River indeed flowed west through Unaweep Canyon, ultimately abandoning it during the Pleistocene (Kaplan et al. 2005; Kaplan 2006). Whether the ancestral Gunnison River carved or merely exhumed Unaweep Canyon, however, remains an open question.

\section{Geomorphic Hints of a Pre-Mesozoic Age}

Among the geomorphic oddities of the inner, crystalline gorge of Unaweep Canyon are numerous amphitheater-like tributary drainages and rills that fail to propagate headward and instead are truncated by Mesozoic strata (fig. 2). Groundwater sapping is a common phenomenon that produces amphitheater landforms in Colorado Plateau sandstones because it occurs where a resistant and porous lithology overlies more friable layers, resulting in seepage and associated weathering at the surface (Baker 1990). The inner gorge of Unaweep Canyon, however, consists entirely of crystalline basement such that groundwater sapping is not a viable mechanism for amphitheater formation. Moreover, Mesozoic siltstone and sandstone commonly extend to within a few meters of the Precambrian crystalline gorge, suggesting the ancestral Gunnison River never encountered any resistance differential between sedimentary and crystalline bedrock (fig. 2).

\section{Sediment Fill in Unaweep Canyon}

Locating and dating sediment fill in Unaweep Canyon is the key to dating the canyon, but few outcrops have been mapped or dated until this study. The existence of significant fill in Unaweep Canyon has been debated; some have assumed only negligible fill (Lohman 1981), although geophysical evidence suggests deposits locally up to $200 \mathrm{~m}$ to nearly $400 \mathrm{~m}$ thick (Oesleby 1978, 2005; Mitchell 1984).

Analysis of road and stream cuts near the western mouth of the canyon ( 1 in fig. 1) reveal two units (fig. 3). The upper unit consists of red-brown (10R $5 / 4$ to $10 Y R 3 / 4$ ) clast-supported and crudely stratified conglomerate with pebbles to $1.5-\mathrm{m}$ boulders within a sandy matrix. The top of this unit forms
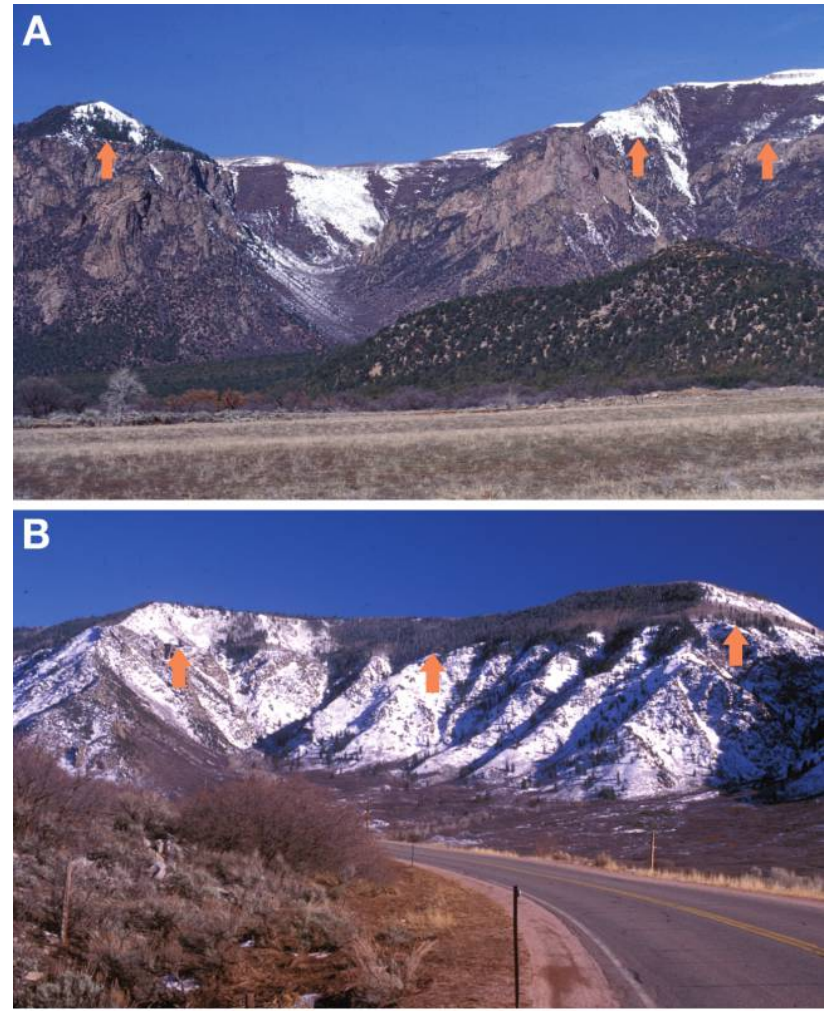

Figure 2. Photographs of the walls of Unaweep Canyon; arrows indicate the nonconformity (Mesozoic-Precambrian) contact. $A$, One of several amphitheater-like hanging valleys located in western Unaweep Canyon (Ushaped, just left of center). The hanging valley is carved into Precambrian basement and does not propagate into the overlying Mesozoic strata but rather is beheaded by the latter. Photo was taken looking west/northwest (see location in fig. 1). $B$, Small rill-like draws (areas in shade) cut into Precambrian basement and beheaded (crosscut) by the largely forested Mesozoic strata above. Note also the lack of recession of the soft Mesozoic strata from the edge of the crystalline basement. Photo was taken looking southeast (see location in fig. 1). These crosscutting relationships suggest that the basement topography predates the Mesozoic.

the modern surface, the debris aprons produced by mass wasting and stream reworking of material eroded from the Unaweep Canyon sidewalls. The basal contact is sharp and planar, extending across Precambrian basement and the lower conglomeratic unit (fig. 3). Clast counts (pebble and larger; $n=609$ ) indicate a mixture of Precambrian basement $(51 \%)$ and Mesozoic strata (49\%). The sand is lithic arkosic with sedimentary rock fragments (table 1; appendix tables A1, A2, available in the online edition or from the Journal of Geology office). A few of the several $(>10)$ samples from the 


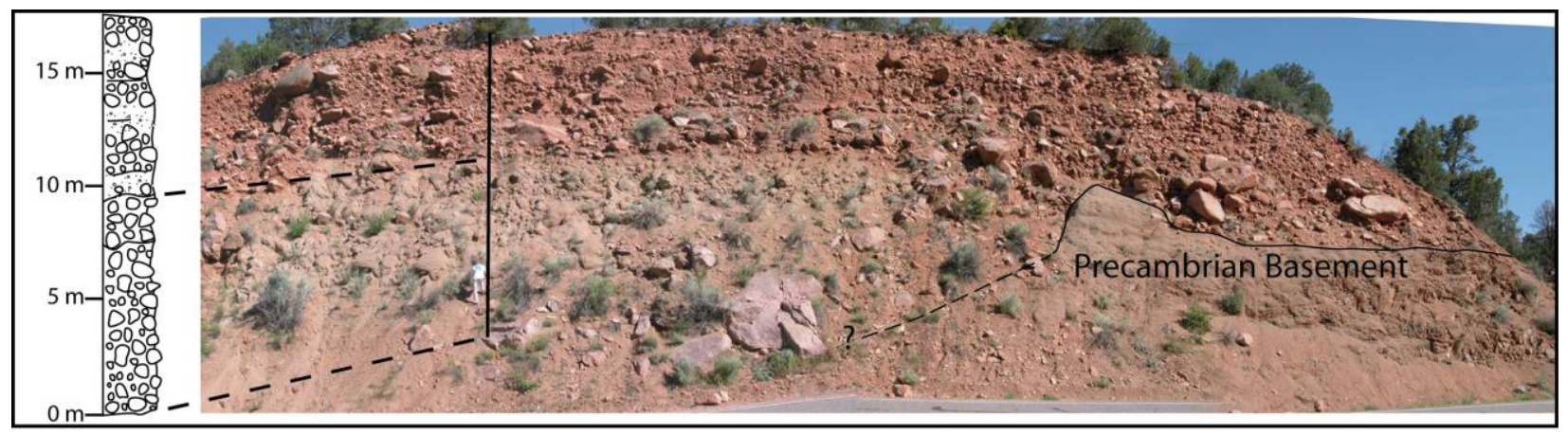

Figure 3. Roadcut in western Unaweep Canyon (1 in fig. 1) exposing a part of the fill of Unaweep Canyon. Photograph shows Precambrian basement (lower right), suspected upper Paleozoic fill (lower left; note person for scale), and Cenozoic debris apron conglomerate (upper) overlying both. Line traces the nonconformity contact.

basal few meters of this unit that were processed for palynomorphs yielded sparse late Paleozoic palynofloras (Densosporites, Lycospora, Florinites, and Vesicaspora), a single Mesozoic pollen grain (Corollina, reported in the Chinle Formation by Litwin [1983]), and a Pseudotsuga (modern evergreen) pollen. The late Paleozoic forms exhibit low values (1-2) of the Thermal Alteration Index (TAI).

Below this, some $7-13 \mathrm{~m}$ of the basal unit is exposed, which consists of a drab gray-brown (5Y 5/ 2 to 10YR 6/2) matrix- to clast-supported massive conglomerate with exclusively Precambrian (local) basement clasts ranging from pebbles to $3-\mathrm{m}$ boulders embedded within a sandy to clayey matrix. The sand composition is arkosic (tables 1, A1, A2). Several samples of matrix (15-25-g samples) subjected to palynological processing were barren, but a few samples yielded sparse and minimally thermally altered (TAI $=1-2$ ) Densosporites, Endosporites, Lycospora, and Thymospora, all palynofloras of Permo-Pennsylvanian age, many of which have been documented from Pennsylvanian strata of the nearby Paradox basin (Kosanke 1995; Rueger 1996).

To further assess the thickness and composition of the fill, we drilled and cored a well in western Unaweep Canyon $7 \mathrm{~km}$ upstream of these outcrops. This well reached a depth of $320 \mathrm{~m}$, still within sediment, before drilling problems mandated abandonment. A "twin" well drilled $30 \mathrm{~m}$ from the first well penetrated Precambrian basement at a depth of $329 \mathrm{~m}$. Sedimentologic, palynologic, provenance, and paleomagnetic analyses conducted on the whole core recovered from the first well enable recognition of three units (fig. 4).

The upper $\sim 160 \mathrm{~m}$ consists of red-brown (10R 5/ 4) clast- to matrix-supported, crudely stratified conglomerate with local sandy-clayey interbeds and clasts of Mesozoic sandstone and Precambrian basement ranging from pebble to boulder size. These deposits are interpreted as traction and mass flows of debris aprons emanating from the canyon walls; the top of this succession forms the modern fan surface. The sand fraction is lithic arkosic with sedimentary rock fragments (upsection) and trace volcanic rock fragments (fig. 4; tables 1, A1, A2). Samples (10) of clayey to sandy material spaced throughout this unit were processed for palynomorphs but were barren except for recent pine and spruce pollen.

A 7-m series of paleosols evinced by carbonate nodules and root traces mark the transition between the middle and upper units of the core. Below this, and extending to $\sim 315 \mathrm{~m}$, the core consists of green-gray (5GY 6/1) to yellow-gray (5Y 72) wellsorted fine sand and clay with abundant dark, macerated leafy and woody carbonaceous debris; the upper $120 \mathrm{~m}$ exhibits a large upwardly coarsening succession (UCS) comprising well-sorted medium-fine sand in $<1-3-\mathrm{m}$ beds with irregular laminations and rare bioturbation, yielding below to very fine sand and clay, olive gray $(5 \mathrm{Y} 5 / 2$ or $5 \mathrm{Y}$ 4/1) to pale brown (5 YR 5/2) in color, with abundant plant fragments and a fetid odor. We tentatively interpret this succession to record deposition in an upwardly shallowing lacustrine to paludal environment. The UCS is lithic arkosic, with locally significant quartz and volcanic rock fragments (fig. 4; tables 1, A1, A2), and samples (6) processed for palynomorphs yielded recent pine and spruce pollen. Below this UCS, well-sorted fine-clayey sand persists to $315 \mathrm{~m}$ and exhibits a shift to a purely arkosic composition (fig. 4; tables 1, A1, A2) and the appearance of Paleozoic palynofloras (Lycospora, Densosporites, Calamospora) 
Table 1. Summary of Sand Framework Mineralogy Data

\begin{tabular}{|c|c|c|c|c|c|c|c|}
\hline Unit & Depth (m) & $n$ & $\mathrm{Q} / \mathrm{F} / \mathrm{L}^{\mathrm{a}}$ & $\mathrm{Q} / \mathrm{F} / \mathrm{R}^{\mathrm{b}}$ & $\mathrm{Ls}^{\mathrm{b}}$ & $\mathrm{Lv}^{\mathrm{b}}$ & $\mathrm{A}^{\mathrm{a}}$ \\
\hline Upper outcrop & na & 3 & $32 / 68 / 0$ & $24 / 55 / 21$ & 8 & 0 & 7 \\
\hline Lower outcrop & na & 4 & $27 / 73 / 0$ & $24 / 70 / 6$ & 0 & 0 & 14 \\
\hline Upper well & 0-159 & 12 & $34 / 65 / \mathrm{tr}$ & $21 / 48 / 31$ & 7 & $\operatorname{tr}$ & 4 \\
\hline Middle well & $159-290$ & 13 & $55 / 42 / 3$ & $43 / 35 / 22$ & 0 & 3 & 2 \\
\hline Middle well & $290-315$ & 8 & $26 / 74 / 0$ & $19 / 62 / 19$ & 0 & 0 & 4 \\
\hline Lower well & $315-320$ & 3 & $27 / 73 / 0$ & $20 / 60 / 20$ & 0 & 0 & 9 \\
\hline
\end{tabular}

Note. $\mathrm{Q}=$ quartz, $\mathrm{F}=$ feldspar, $\mathrm{L}=$ lithics, $\mathrm{R}=$ rock fragments, $\mathrm{Ls}=$ sedimentary rock fragments, $\mathrm{Lv}=$ volcanic rock fragments, and $\mathrm{A}=$ amphiboles. Numbers are percentages. $\operatorname{tr}=$ trace amount $(>0.2 \%,<0.5 \%)$

${ }^{a}$ Gazzi-Dickinson method.

b Traditional method (details in the appendix, available in the online edition or from the Journal of Geology office).

in one of three samples. Most paleomagnetic samples $\left(\mathrm{N} / \mathrm{N}_{\mathrm{o}}=31 / 32\right)$ yielded an intermediate-temperature $\left(250^{\circ}-500^{\circ} \mathrm{C}\right)$ steep inclination averaging $-46.5^{\circ}$; a few $\left(\mathrm{N} / \mathrm{N}_{\mathrm{o}}=5 / 32\right)$ yielded a high-temperature $\left(350^{\circ}-580^{\circ} \mathrm{C}\right)$ shallow component averaging $-8.0^{\circ}$ (fig. 4 ; table A3).

The lowest unit of the core (basal $5 \mathrm{~m}$ ) is a pale to dark yellowish brown (10YR 6/2) moderately indurated interval of angular basement clasts up to $60 \mathrm{~cm}$ in diameter scattered within a clayey granule matrix. The sand is arkosic but is distinguished from the upper and middle well units primarily by an absence of sedimentary and volcanic rock fragments (fig. 4; tables 1, A1, A2). Samples (4) processed for palynomorphs contained recent pine and spruce pollen; however, three of four samples yielded sparse but consistently present and identifiable late Paleozoic palynofloras comprising Lycospora, Densosporites, and Calamospora. Like the other recovered Paleozoic forms, all exhibit minimal thermal alteration (TAI = 1-2). These samples were processed twice, the second time using new sample containers as a check for contamination, with the same results. Paleomagnetic samples from this interval yielded a high-temperature $\left(200^{\circ}-675^{\circ} \mathrm{C}\right)$ shallow component averaging $-8.6^{\circ}\left(\mathrm{N} / \mathrm{N}_{\mathrm{o}}=8 / 10\right.$; fig. 4; table A3).

\section{Interpretation: The Age of Unaweep Canyon}

Provenance Data. Here, we integrate the provenance, palynology, and paleomagnetic data to hypothesize that the inner gorge of Unaweep Canyon contains fill of late Paleozoic age (fig. 4). Modern Unaweep Canyon exposes the Precambrian crystalline core and Mesozoic sedimentary carapace of the Uncompahgre Plateau; thus, material entering the canyon via side-canyon tributaries that fed the recently deposited debris aprons ought to reflect contributions from both the Precambrian and Mesozoic. Furthermore, the Gunnison River drains the Oligocene intermediate volcanics of the San Juan
Mountains, so the presence of volcanic (andesitic) clasts indicates a Gunnison provenance (Cater 1966; Aslan et al. 2005). Indeed, terraces of andesite-bearing gravels at the western mouth of Unaweep Canyon establish the former presence of the ancestral Gunnison River (e.g., Cater 1966; Kaplan et al. 2005; Kaplan 2006) and indicate that the canyon was a topographic entity at that time. The terraces marking the western end of this ancient axial drainage system are buried by conglomeratic debris aprons that form the modern surface (Kaplan et al. 2005; Kaplan 2006).

The similar compositions of the upper conglomerate units in both outcrop and core is not surprising given that these units form the modern surface of Unaweep Canyon. The middle unit of the core contains both Mesozoic sedimentary rock fragments that indicate a post-Mesozoic age and volcanic rock fragments that reflect a post-Oligocene age and Gunnison River provenance. The absence of sedimentary and volcanic material in the lowest unit of the outcrop and core provides no direct age information but is not consistent with a postPaleozoic age, since transverse and axial drainages of Unaweep Canyon transported Mesozoic sedimentary and Cenozoic volcanic material, respectively, into the canyon.

Palynological Data. Pine and spruce populate various elevations in the study area, hence pollen from these sources is ubiquitous and occurs in both the outcrop and well section. Sources for reworked palynomorphs include strata exposed in the axial and tributary drainages flowing into Unaweep Canyon. Mesozoic strata cap the Uncompahgre Plateau; the Gunnison River drains volcanics, Precambrian rocks, and Mesozoic strata en route to its former path through Unaweep Canyon. The presence of a single grain of the Mesozoic Corollina in the upper conglomerate of the West Creek exposure was probably reworked from the Mesozoic strata rimming Unaweep Canyon; a variety of late Paleozoic palynofloras with low TAI values in both the outcrop units and the basal unit of the core is more 


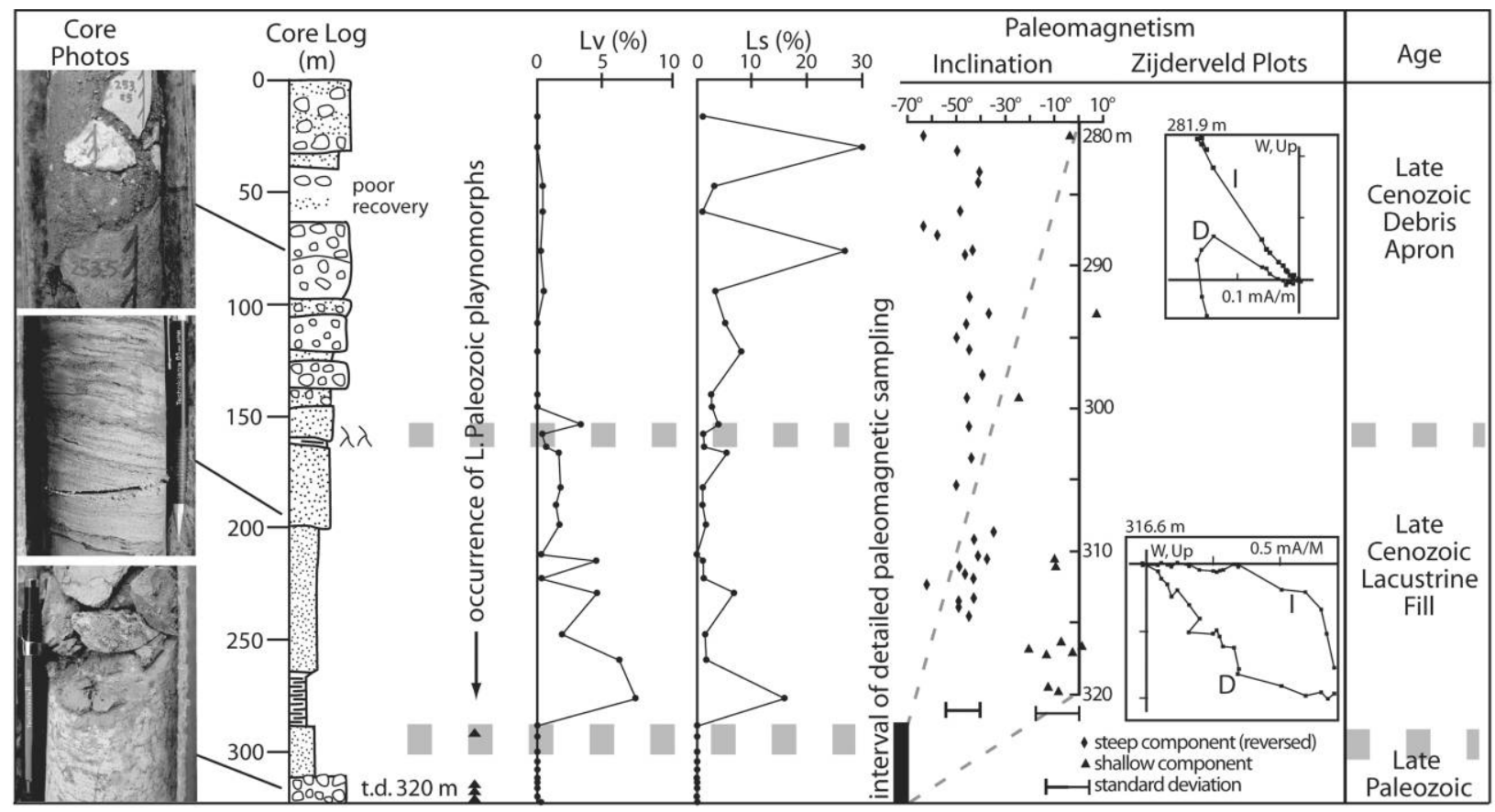

Figure 4. Core data from the well site (2 in fig. 1) in western Unaweep Canyon. Columns show lithologic log of core and representative core photos, occurrence of Paleozoic palynomorphs, provenance data $(L v=$ volcanic rock fragments, $L s=$ sedimentary rock fragments), and paleomagnetic data, with inferred ages at right. Note that the inclination data shown are for the basal $40 \mathrm{~m}$ of the core. For the Zijderveld plots, $I=$ inclination data, $D=$ declination data, and demagnetization steps ranged from $0^{\circ}$ to $480^{\circ} \mathrm{C}$ for sample 281.9 and $0^{\circ}$ to $650^{\circ} \mathrm{C}$ for sample 316.6.

puzzling because no upstream sources exist for these grains. For example, palynomorphs recovered from the upper Paleozoic section of nearby ARM basins exhibit TAIs of $4-5$, associated with significant burial (Tramp et al. 2004). We thus infer that the abrupt appearance of late Paleozoic palynofloras with minimal TAIs in the lowest unit of the core and outcrop is best explained by the presence of upper Paleozoic strata within the basal canyon fill. Given the weakly consolidated nature of the entire sediment column, the presence of recent pollen in the basal unit likely reflects contamination attributable to infiltration from immediately superjacent strata (e.g., Kelso 1994).

Paleomagnetic Data. Principal component analysis (Kirschvink 1980) of thermally demagnetized samples yields steep and shallow remanent components within the lower $40 \mathrm{~m}$ of core. Above 315 $\mathrm{m}$, steep $\left(\mathrm{x}=-46.5^{\circ}, \sigma=7.16\right)$ and shallow $(\mathrm{x}=$ $\left.-8.0^{\circ}, \sigma=11.95\right)$ inclinations are present that unblock at a maximum of $575^{\circ} \mathrm{C}$. Furthermore, the shallow component obtained in this interval is always accompanied by an intermediate-temperature steep component. Below 315 m, however, only a characteristic remanent magnetization (ChRM) with shallow $\left(x=-8.6^{\circ}, \sigma=7.38\right)$ inclinations that unblock at a maximum of $675^{\circ} \mathrm{C}$ is present. Using the statistical maximum $(-15.98)$ and minimum $(-1.22)$ inclination values of the shallow component, paleolatitudes of $\pm 8.1^{\circ}$ and $\pm 0.6^{\circ}$, respectively, are calculated that are consistent with a late Paleozoic age using paleogeographic reconstructions of Scotese (1997). The steep inclinations are consistent with a Cenozoic component. The ChRM is interpreted to reside in hematite, based on the maximum unblocking temperature of $675^{\circ}$. The ChRM could be a detrital remanent magnetization (DRM), a postdepositional DRM, or an early chemical remanent magnetization. Additional studies are underway to further assess the origin of the ChRM.

\section{Discussion: An Ancient Landscape Exhumed and Backfilled}

The combined provenance, palynologic, and paleomagnetic data indicate that the basal fill within the inner gorge of Unaweep Canyon, represented by the 
lower conglomeratic unit in outcrop and the lowest unit in the well, dates from the late Paleozoic, providing a minimum age for the ancestral canyon. However, we favor a late Paleozoic age rather than an older age, owing to the composition of the late Paleozoic Cutler Formation, which onlaps Precambrian basement at the western mouth of Unaweep Canyon. The Cutler Formation comprises firstcycle arkose that reflects local derivation from the Precambrian of the Uncompahgre uplift (Werner 1972). If ancestral Unaweep Canyon predated the late Paleozoic and was buried and re-exhumed during the late Paleozoic, it would have shed secondcycle material into the Cutler Formation. Hence, we reason the topography that formed during the late Paleozoic was preserved owing to rapid burial by late Paleozoic strata and was then covered by the thick succession of Mesozoic strata typical of the region.

By Neogene time, the (ancestral) Gunnison River began exhuming the old canyon. Significant quartz and volcanic sand within the middle (lacustrine) interval of the core reflect this ancestral Gunnison River, which exhumed the buried gorge and then became blocked, leading to backfilling and ultimate abandonment of the canyon. A blockage is also consistent with the absence of the lacustrine unit in the outcrop exposure (fig. 4). We speculate that the blockage could have resulted from a large slope failure in the narrow "neck" near the western canyon mouth. The youngest units in both outcrop and core comprise the debris aprons that form the modern surface and record slope retreat of the inner gorge by mass wasting following abandonment by the ancestral Gunnison River. In this scenario, Unaweep Divide originated as the West Creek and East Creek drainages propagated headward, and it bears no relation to either the modern Gunnison River or Uncompahgre neotectonics. This explanation reconciles with the absence of Gunnison river gravels within the canyon and the lack of evidence of Uncompahgre neotectonics anywhere in the region.

\section{Implications: Paleogeomorphology as a Tectonic and Climatic Indicator}

Landforms dating from the early Cenozoic and the Mesozoic have been documented from several regions, and even Paleozoic and pre-Paleozoic landscapes are known to exist (e.g., Ambrose 1964; Twidale 1994; Twidale and Campbell 1995; Nott 1995; Visser et al. 1997). Hence, recognition of old landscapes is not new, particularly in the Gondwanan continents, but their extent and implications re- main underappreciated (Twidale 2003). Of the various types of ancient landscapes, exhumed forms are less puzzling than "etch" or "epigene" types because the persistence of the latter conflicts with Huttonian concepts (Hutton 1788) of constant change (Twidale 2003). Twidale (2003) noted that factors conducive to such landform antiquity, common to Gondwanan continents such as Australia, include long-persistent anorogenic settings and planation (low-relief, generally low-elevation) landscapes. Nott (1995) also noted that landscape longevity set cratonal landscapes apart from those of other tectonic settings (cf. Young 1983). The Eocene erosion surface of the modern Rockies is an example of an ancient form in a modern orogenic belt (Epis and Chapin 1975) but one that is undergoing active dissection and thus may not persist. Ancestral Unaweep Canyon is an exhumed form and hence was protected from destruction until only recently; however, its survival is odd because unlike other examples of ancient landforms, it occurs in a region characterized today-but more notably during the late Paleozoic-by profound orogenesis and significant relief far from a cratonal setting. Accordingly, its preservation bears on our understanding of the enigmatic intraplate orogenesis that spawned its genesis in addition to the climatic setting that imparted its form.

During the ARM intraplate orogeny of the late Paleozoic, profound uplift on the Uncompahgre highland resulted in copious siliciclastic material being shed to neighboring basins. The Uncompahgre uplift and the many other highlands of the ARM are thought to have gradually eroded until they were eventually buried by continental and marine Mesozoic strata, ultimately reemerging during the Cenozoic orogenesis that led to the modern Rocky Mountains (e.g., DeVoto 1980). If this were so, however, Unaweep Canyon should not have survived. Its survival, together with the late Paleozoic rather than Mesozoic age of its fill, indicates that the uplift did not wear down over 50-100 Ma but rather succumbed to active subsidence sufficient to bury a $\sim 1-\mathrm{km}$-deep canyon immediately following the uplift's tectonic apogee in Pennsylvanian-early Permian time. The processes that enabled this intraplate highland to veer from uplifting and denuding to subsiding within a geologically brief time are unknown, and they challenge our understanding of intraplate tectonic processes.

In addition to raising new questions about the late Paleozoic tectonism that enabled its survival, however, recognition of the great age of Unaweep Canyon provides the opportunity to investigate the climatic conditions prevailing during its formation. 
Geomorphologic attributes of Unaweep Canyon have long been considered enigmatic because many features of the canyon appear more consistent with a glacial rather than fluvial genesis (see earlier citations). A priori, a glacial origin appears inconsistent with the late Paleozoic equatorial setting of the region. Although tropical glaciation is permissible given sufficient elevation, the requisite 4-5$\mathrm{km}$ elevation needed for modern or recent tropical glaciers is at odds with the Permo-Pennsylvanian burial of the canyon documented here because it implies large-scale orogenic collapse of the Uncompahgre highland that is not supported by structural evidence. The alternative implies invoking a late Paleozoic climate that, at least periodically, enabled relatively low-elevation glaciation at the equator, an admittedly extreme hypothesis. The ultimate origin of the canyon requires further geomorphologic and sedimentologic analyses, but it serves to highlight the utility of paleogeomorphology as an indicator for paleotectonic and paleoclimatic analyses.

\section{A C K N O W L E D G M E N T S}

Funding was provided by the National Science Foundation (grants EAR-0001052, EAR-0230332). We owe special thanks to T. Himes and Himes Drilling for providing major in-kind support and expertise for drilling operations, R. Massey (Massey Ranch) for property access, J. Stowell of Mt. Sopris Instruments for well logging, and the Powells (Gateway, CO) for logistical support during field studies. We also thank C. R. Twidale and an anonymous reviewer for constructive comments on an earlier version of this manuscript. Finally, we thank several colleagues for encouraging discussions, notably C. Chase, P. DeCelles, and V. Matthews.

\section{R E F E R E N C E S C I T E D}

Ambrose, J. W. 1964. Exhumed paleoplains of the Precambrian Shield of North America. Am. I. Sci. 262: 817-857.

Aslan, A.; Livaccari, R.; Hood, W.; Betton, C.; and Garhart, A. 2005. Geological history of the Uncompahgre Plateau and Unaweep Canyon: day one guidebook. In Richard, G., and Wolny, D., comps. Geol. Soc. Am. Rocky Mountain Section field trip guidebook. Grand Junction, CO, Grand Junction Geological Society, CDROM.

Baker, V. R. 1990. Spring sapping and valley network development. In Higgins, C. G., and Coates, D. R., eds. Groundwater geomorphology: the role of subsurface water in earth-surface processes and landforms. Geol. Soc. Am. Spec. Pap. 252:235-265.

Cater, F. W., Jr. 1966. Age of the Uncompahgre uplift and Unaweep Canyon, west-central Colorado. U.S. Geol. Surv. Prof. Pap. 550-C:C86-C92.

Cole, R. D., and Young, R. G. 1983. Evidence for glaciation in Unaweep Canyon, Mesa County, Colorado. In Averett, W. R., ed. Northern Paradox Basin-Uncompahgre uplift field trip guidebook. Grand Junction, CO, Grand Junction Geological Society, p. 73-80.

DeVoto, R. H. 1980. Pennsylvanian stratigraphy and history of Colorado. In Kent, H. C., and Porter, K. W., eds. Symposium on Colorado geology. Denver, Rocky Mountain Association of Geologists, p. 71-101.

Epis, R. C., and Chapin, C. E. 1975. Geomorphic and tectonic implications of the post-Laramide, late Eocene erosion surface in the southern Rocky Mountains. In Cenozoic history of the southern Rocky Mountains. Geol. Soc. Am. Mem. 144:45-74.

Gannett, H. 1882. The Unaweep Cañon (Colorado). Pop. Sci. Monthly 20:781-786.
Hunt, C. B. 1956. Cenozoic geology of the Colorado Plateau. U.S. Geol. Surv. Prof. Pap. 279.

- 1969. The Colorado River region and John Wesley Powell: geologic history of the Colorado River. U.S. Geol. Surv. Prof. Pap. 669-C:C59-C130.

Hutton, J. 1788. Theory of the earth; or, an investigation of the laws observable in the composition, dissolution and restoration of land upon the globe. R. Soc. Edinb. Trans. 1:209-304.

Kaplan, S. A. 2006. Revealing Unaweep Canyon: the Late Cenozoic exhumation history of Unaweep Canyon as recorded by gravels in Gateway, Colorado. MS thesis, University of Oklahoma, Norman.

Kaplan, S. A.; Soreghan, G. S.; Sweet, D.; and Blum, M. D. 2005. The history of the ancestral Gunnison River through western Unaweep Canyon and Gateway (Colorado). Rocky Mountain Section Geol. Soc. Am. Abstr. Program 36, 7:35.

Kelso, G. K. 1994. Pollen percolation rates in Euroamerican-era cultural deposits in the northeastern United States. I. Archaeol. Sci. 21:481-488.

Kirschvink, J. L. 1980. The least-squares line and plane and the analysis of palaeomagnetic data. Geophys. I. R. Astr. Soc. 62:699-718.

Kosanke, R. M. 1995. Palynology of part of the Paradox and Honaker trail formations, Paradox basin, Utah. U.S. Geol. Surv. Bull. 2000-L.

Litwin, R. J. 1983. Fertile organs and in situ spores of ferns from the Late Triassic Chinle Formation of the Colorado Plateau (Arizona and New Mexico), with discussion of the associated dispersed spores. MS thesis, Pennsylvania State University, State College.

Lohman, S. W. 1961. Abandonment of Unaweep Canyon, Mesa County, Colorado, by capture of the Colorado 
and Gunnison Rivers. U.S. Geol. Surv. Prof. Pap. 424B:B144-B146.

1965. Geology, artesian water supply, Grand Junction area, Colorado. U.S. Geol. Surv. Prof. Pap. 451: 69-74.

- 1981. Ancient drainage changes in and south of Unaweep Canyon, southwestern Colorado. In Epis, R. C., and Callender, J. F., eds. Western slope Colorado. New Mexico Geological Society Guidebook no. 32. Socorro, NM, New Mexico Geological Society, p. 137143.

McQuarrie, N., and Chase, C. 2000. Raising the Colorado Plateau. Geology 28:91-94.

Mitchell, J. P. 1984. Shallow seismic reflection data acquisition and processing techniques applied to the delineation of buried bedrock topography. MS thesis, Purdue University, Lafayette, IN.

Morgan, P., and Swanberg, C. A. 1985. On the Cenozoic uplift and tectonic stability of the Colorado Plateau. I. Geodyn. 3:39-63.

Nott, J. 1995. The antiquity of landscapes on the North Australian Craton and the implications for theories of long-term landscape evolution. I. Geol. 103:19-32.

Oesleby, T. W. 1978. Uplift and deformation of the Uncompahgre Plateau: evidence from fill thickness in Unaweep Canyon, west-central Colorado. MS thesis, University of Colorado, Boulder.

- 2005. Thick sediment fill in Unaweep Canyon: implications for the history of the Uncompahgre uplift, western Colorado. In Richard, G., and Wolny, D., comps. Geol. Soc. Am. Rocky Mountain Section field trip guidebook. Grand Junction, CO, Grand Junction Geological Society, CD-ROM.

Peale, A. C. 1877. Geological report on the Grand River district. U.S. Geol. and Geogr. Surv. of the Territories, ninth annual report, p. 31-102.

Pederson, J. L.; Mackley, R. D.; and Eddleman, J. L. 2002. Colorado Plateau uplift and erosion evaluated using GIS. GSA Today 12:4-10.

Perry, T. W., IV, and Annis, D. R. 1990. Pleistocene history of the Gunnison R. in Unaweep Canyon, Colorado and implications for Colorado Plateau uplift. Cordilleran Section Geol. Soc. Am. Abstr. Program 22, 3: 75.

Rueger, B. F. 1996. Palynology and its relationship to climatically induced depositional cycles in the Middle Pennsylvanian (Desmoinesian) Paradox Formation of southeastern Utah. U.S. Geol. Surv. Bull. 2000-K.

Scotese, C. R. 1997. Paleogeographic atlas: PALEOMAP progress report 90-0497. Arlington, Department of Geology, University of Texas.
Sinnock, S. 1981. Pleistocene drainage changes in Uncompahgre Plateau-Grand Valley region of western Colorado, including formation and abandonment of Unaweep Canyon: a hypothesis. In Epis, R. C., and Callender, J. F., eds. Western slope Colorado. New Mexico Geological Society Guidebook no. 32. Socorro, NM, New Mexico Geological Society, p. 127-136.

Spencer, J. 1996. Uplift of the Colorado Plateau due to lithospheric attenuation during Laramide low-angle subduction. I. Geophys. Res. 101:13,595-13,609.

Steven, T. A. 2002. Late Cenozoic tectonic and geomorphic framework surrounding the evaporite dissolution area in west-central Colorado. In Kirkham, R. M.; Scott, R. B.; and Judkins, T. W., eds. Late Cenozoic evaporite tectonism and volcanism in west-central Colorado. Geol. Soc. Am. Spec. Pap. 366:15-30.

Tramp, K. L.; Soreghan, G. S.; and Elmore, R. D. 2004. Paleoclimatic inferences from paleopedology and magnetism of the Permian Maroon Formation loessite, Colorado, USA. Geol. Soc. Amer. Bull. 116:671686.

Twidale, C. R. 1976. On the survival of palaeoforms. Amer. I. Sci. 276:1138-1176.

. 1994. Gondwanan (Late Jurassic and Cretaceous) palaeosurfaces of the Australian craton. Palaeogeogr. Palaeoclimatol. Palaeoecol. 112:157-186.

- 1998. Antiquity of landforms: an "extremely unlikely" concept vindicated. Aust. I. Earth Sci. 45:657668.

- 2003. "Canons" revisited and reviewed. Lester King's views of landscape evolution considered 50 years later. Geol. Soc. Am. Bull. 115:1155-1172.

Twidale, C. R., and Campbell, E. M. 1995. Pre-Quaternary landforms in the low latitude context: the example of Australia. Geomorphology 12:17-35.

Visser, J. N. J.; van Niekerk, B. N.; and van der Merwe, S. W. 1997. Sediment transport of the late Palaeozoic glacial Dwyka Group in the southwestern Karoo basin. S. Afr. J. Geol. 100:223-236.

Werner, W. G. 1972. Sedimentology of the Cutler Formation (Pennsylvanian-Permian) near Gateway, Colorado, and Fisher Towers, Utah. MS thesis, University of Missouri, Columbia.

Yeend, W. E. 1969. Quaternary geology of the Grand and Battlement Mesa Areas, Colorado. U.S. Geol. Surv. Prof. Pap. 617.

Young, R. W. 1983. The tempo of geomorphological change: evidence from southeastern Australia. I. Geol. 91:221-230. 